\title{
The Short-Term Results of Da Vinci Robotic Rectal Resection for Malignant and Benign Tumors
}

\author{
Andrey Atroshchenko* \\ Head of department of coloproctology, Surgeon, Oncologist, Coloproctologist, Russia
}

Submission: August 25, 2017; Published: August 15, 2018

"Corresponding author: Andrey Atroshchenko, Head of department of coloproctology, Surgeon, Oncologist, Coloproctologist, Russia, Tel: $+7(926)-$ 265-58-85; Email: a.atroshenko@mknc.ru

\section{Introduction}

The history of rectal surgery is about 300 years, since 1739 y. when Jean Faget performed the first extirpation of the rectum; in 1899 the English surgeon William Ernest Miles developed a method of rectum extirpation, which almost unchanged by nowadays [1]. Theodor Kocher performed the first trans sacral rectal resection in 1874. This method was called «posterior rectal resection». Carl Gussenuer performed the first anterior rectal resection by trans abdominal access in 1879. The first colon anastomosis performed in 1910 by the Donald Balfour [1]. The first description about fascial way of rectum mobilization was published in monograph of the famous Russian surgeon Semen Abramovich Holdin: Malignant neoplasms of the rectum, published in 1955. Later this technic was widely replicated and patented by the English surgeon R.B. Heald as a method of rectal removing with total mesorectal exscision (TME) in 1982y [2-5]. The standardization of fascial plane rectal mobilization technic with TME has opened a new page in surgical treatment of the rectal cancer and allowed significantly reduce the number of local recurrence and increase the disease-free survival.

The period between 1990-2000 yy., characterized the introduction of minimally invasive laparoscopic procedures in colorectal surgery $[6,7]$. The first laparoscopic rectal resection performed in 1990y. by Patrick Leahy [6-8]. In 2006 y. the Italian surgeon Pigazzi performed the World's first rectal resection with TME, using by Da Vinci robotic system $[9,10]$. The technological progress opens a new era of colorectal surgery with ultraprecision technic. Surgical technic for rectal surgery has several special features: a limited narrow field of the small pelvic cavity, closest of important autonomic nervous system at surgical plane, the importance of the rectal fascia preserving during rectal mobilization as the main oncological principle of ablastics $[6,7,9]$. The emergence of robotic surgical technologies allowed improving the quality of visualization and surgery convenience, deprived of intentional jitter manipulators - that could increase accuracy during rectal mobilization and autonomic nervous system preservation [9,11-13].
The analysis of the results for Da Vinci robotic rectal surgery is the most actual topic of modern surgery and introduction of the robotic surgery for complex surgical cases - one of the perspective tasks. The aim of the study is to improve the surgical treatment results for benign and malignant rectal tumors due to introduction of the ultra - precision robotic technic.

\section{Material and Methods}

Since 2014 - 2016 yy we analyzed the results of 26 robotic rectal resections performed with Da Vinci system (Intuitive Surgical, Inc., Sunnyvale, CA, USA). All patients had a standard scheme of the preoperative investigation: MRI, CT-scan and colonoscopy with biopsy, morphological verification, CEA, CA19.9. General patient's condition estimated by ASA scale, clinical and biochemical blood tests. The pelvic organs function estimated by Wexner Scale, rectal manometry, sphincterometry; IPSS score, residual urine level for urinary function survey. The postoperative pain estimated by "Visual-analogue pain intensity scale" and "brief pain scale". The quality of life estimated by QOLscale.

\section{Surgical technic}

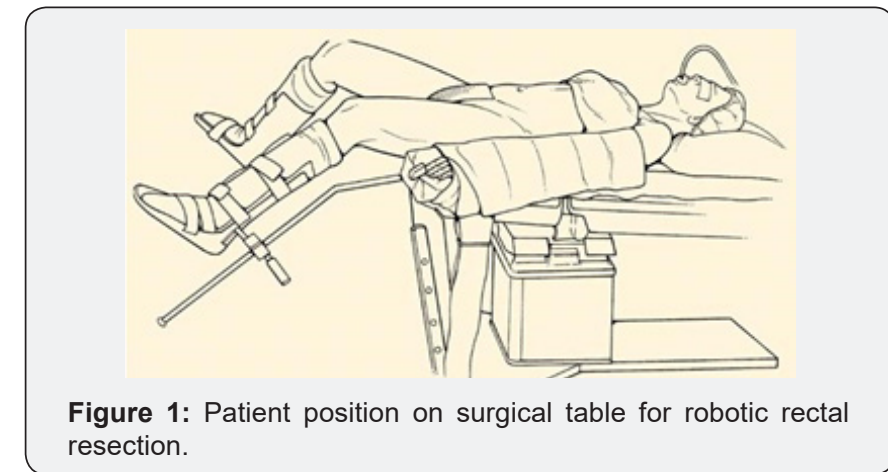

The first 10 procedures we performed by the hybrid technic: first, we mobilized left side of the colon laparoscopicaly, then we docked the Da Vinci system and mobilized the rectum in embryonic lay according TME technic, performed 
lymphadenectomy with robotic system. Other 16 procedures we've done almost by the robotic technic without laparoscopy assistance. At the Figure 1 showed the patient position on surgical table with Trendelenburg position, slightly knee fold and legs divided. At the Figure 2 showed the robotic and assistant trocars position.
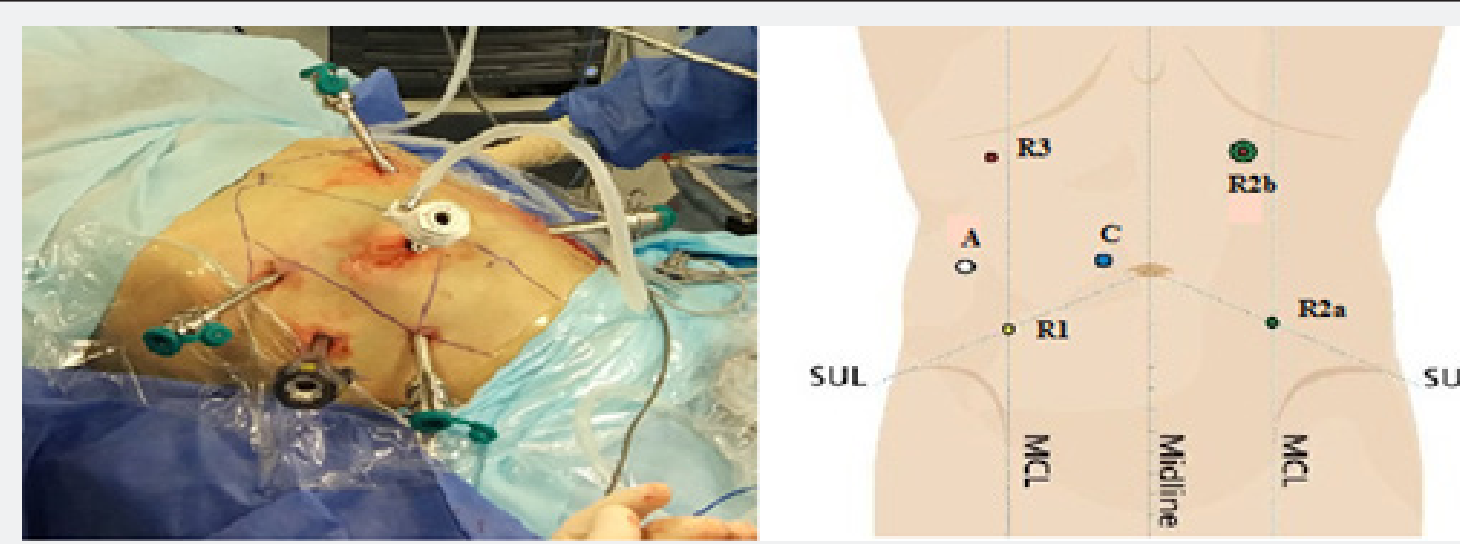

Figure 2: Trocars position (scheme): camera port - C $(12 \mathrm{~mm})$ placed 3-4 $\mathrm{cm}$ upper the umbilicus and 3-4 $\mathrm{cm}$ to the right. The trocars position for robotic arms: R1, R2, R3 (8mm): R1-at the right flank - point of intersection the line connecting the umbilicus with the right anterior superior spine and the right mediaclavicular line; R2a.

First 10 procedures we used robotic trocars for laparoscopic colon mobilization, then Da Vinci system docking as show on the Figure 2. Other 16 procedures performed only with robotic system, using one-docking technique maneuver, changing the robotic arms position during the different steps of surgery (main vessels dissection, mobilization of the sigmoid colon, descend colon, left colic flexure - arm 1 placed in R1 position, arm 2 - R2b position, arm $3-\mathrm{R} 3$ position. For rectal mobilization in pelvic floor we moved the arm 2 to R2a position).

First, at the start of surgery we do the "vascular isolation of the tumor" - as main oncological principals. Initially, the peritoneum was opened above the right iliac artery and further over the abdominal part of the aorta up to the inferior mesenteric artery (IMA) not reaching $1-1.5 \mathrm{~cm}$ to the visible part of the lower horizontal branch of the duodenum. With the correct implementation of this stage, after the dissection of the peritoneum, a loose interfascial space opened - an embryonic layer separating the fibrous tissue of the mesentery of the sigmoid colon from the para aortic adipose tissue, and below the mesorectal tissue from the presacral fascia. Further mobilization was carried out in the embryonic layer. This method is important, because removed adipose tissue with the lymphatic collectors "en-block"- the main oncological principles of ablastics.

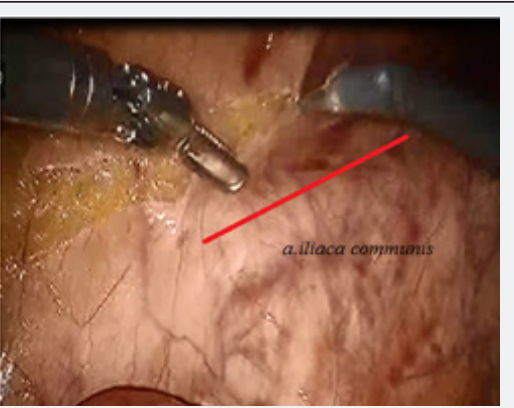

Figure 3: Dissection of the medial peritoneum above the aorta and right iliac artery.
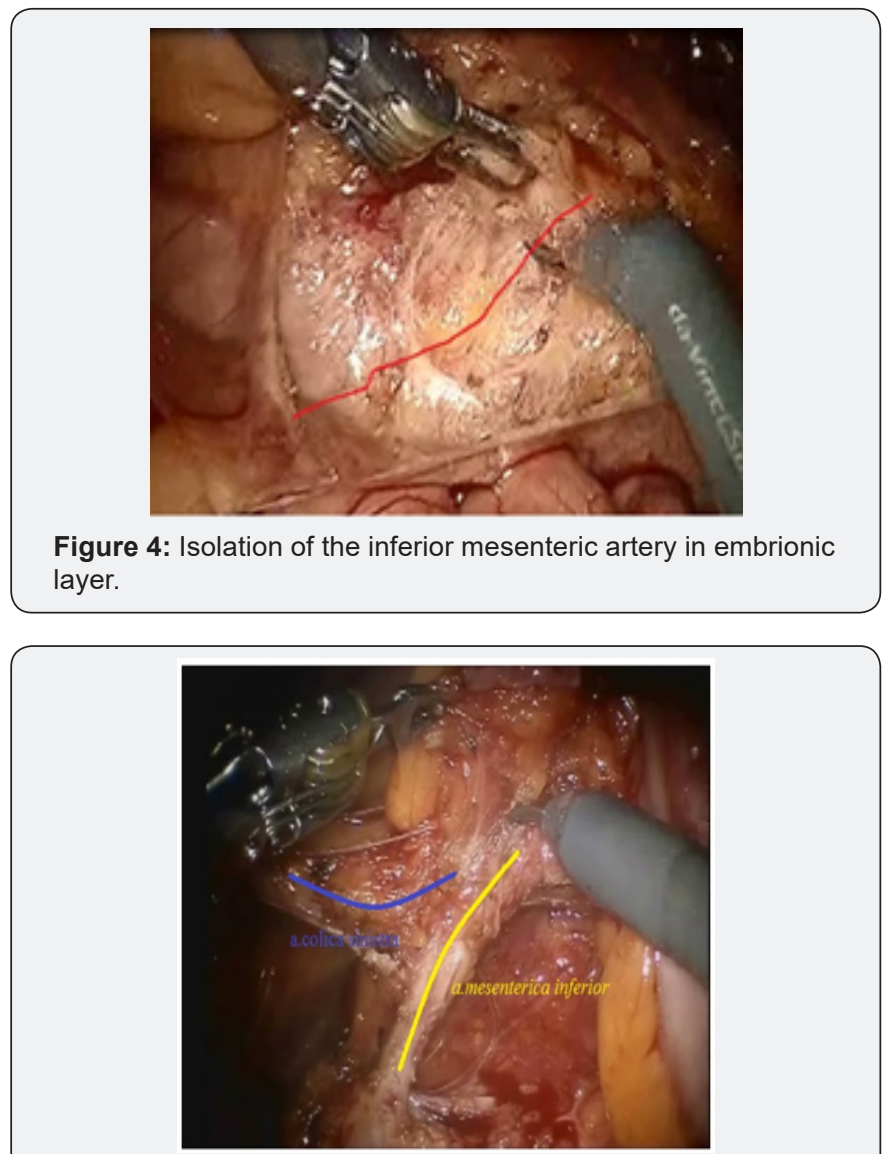

Figure 5: Mobilized trunk of the inferior mesenteric artery from base to point of diviation a.colica sinistra.

After IMA mobilization at base, lymphadenectomy is performed along this trunk to the site and distally to the left colic artery (a. colica sinistra). In this place we are clipping and crossing the IMA. Thus, a. colica sinistra have preserved and the adipose tissues from the base of IMA have removed. Then the 
lower mesenteric vein clipped and intersected. This stage of the surgery does not actually differ from that laparoscopic technique
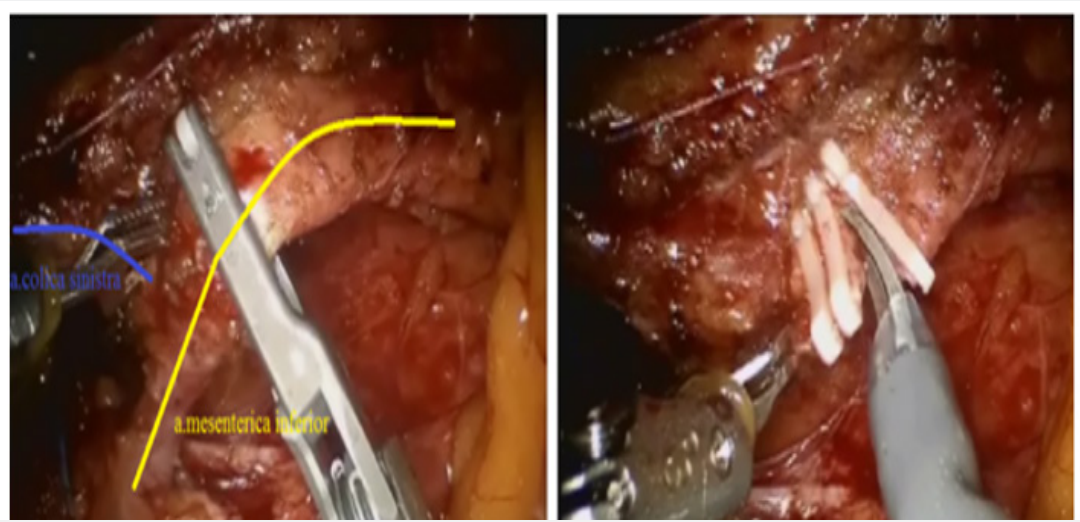

Figure 6a\&b: Clipping and transecting of the inferior mesenteric artery below a.colica sinistra.

Further, the peritoneum of the left lateral canal dissected, the descending colon mobilized, and left flexure of the colon mobilized. When the mobilization of the left colic flexure completed, the robot arm 2 moved from position R2b to R2a position and then rectal mobilization continued. The entrance to the pelvic cavity performed by dissection of the pelvic peritoneum on the right side and mobilization of the rectum along the posterior and anterior semicircle.

Further mobilization continued along the back wall and the left semicircle and then along the front wall (Figures 7-10). Depending on the tumor location we performed total or partial mobilization of the mesorectal adipose tissue. Mobilization of the rectum with mesorectal adipose tissue was carried out in compliance with the principle of facial removal of the organ (Figures 7-10). When the mobilization of the rectum performed, it transected by the Echelon flex linear stapler (yellow or blue cassettes, 60 or $40 \mathrm{~mm}$ ) or Endo - Gia Universal Roticulator linear stapler (purple cassettes 45 and $60 \mathrm{~mm}$ ) (Figure 11). Intracorporeal anastomosis perfomed with circular stapler (Figure 12). Then, after finishing the operation, surgeon cheked the quolity of mesorecum exscision and tumor localization, proximal, distal and lateral bordies (Figure 13).
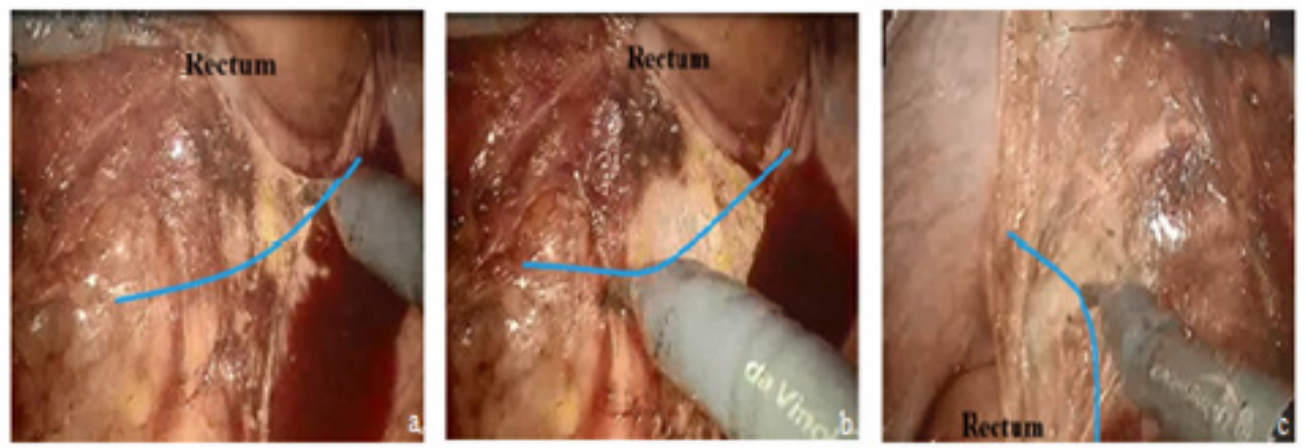

Figure 7: Mobilization of the rectum and mesorectum along the right semicircle (the color line shows the way of mobilization along interfacial space). A- dissection of the pelvic peritoneum on the right side; B- mobilization of the rectum along the right - posterior wall in interfacial layer; C - mobilization on the right wall.
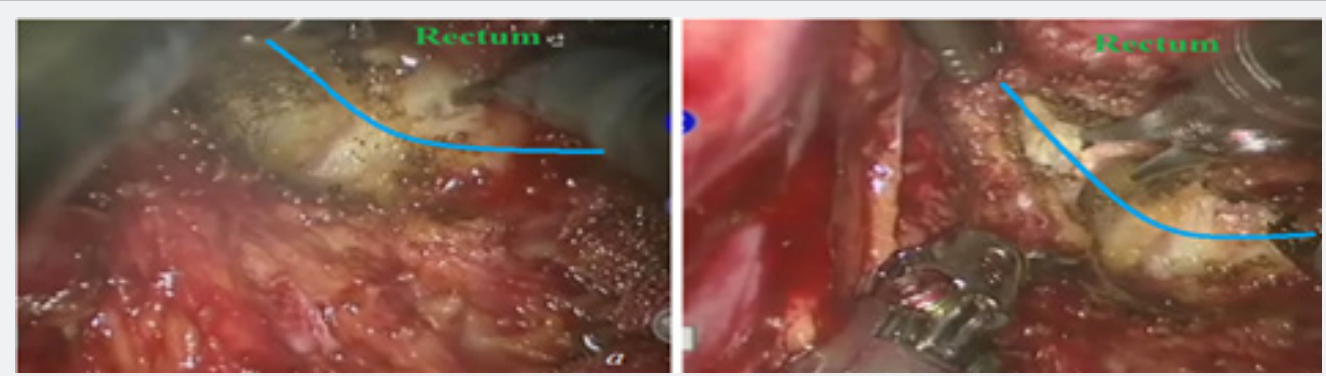

Figure 8: Mesorectum and rectual mobilization in the left posterior semicircle (the color line shows the roote which is necessary to mobilize the interfascial space). A - mobilization of the back wall; B - mobilization on the left wall. 


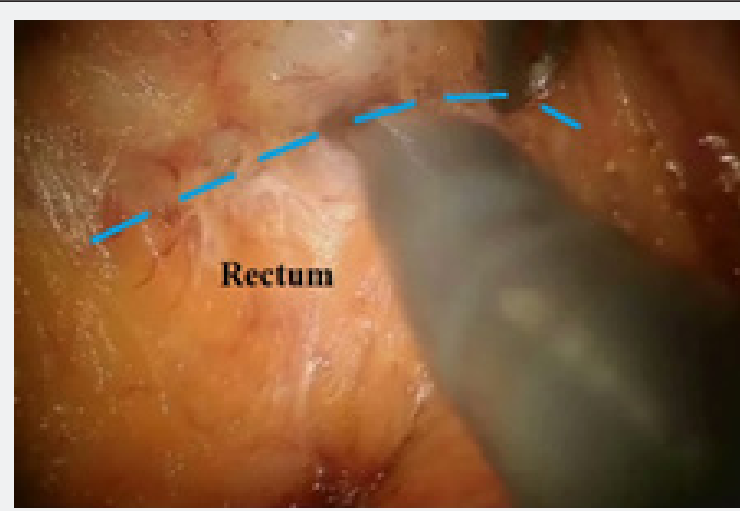

Figure 9: Mobilization of the anterial wall of the rctum.

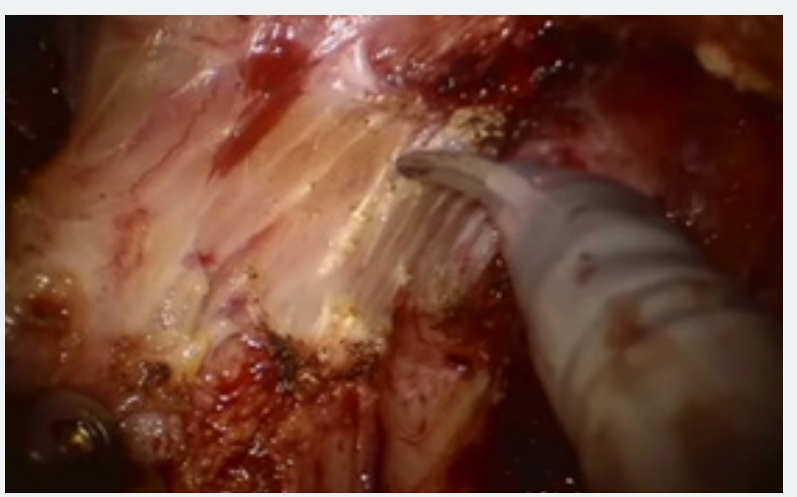

Figure 10: Totall mesorectum exscision (TME) at the bottom of the pelvic floor.

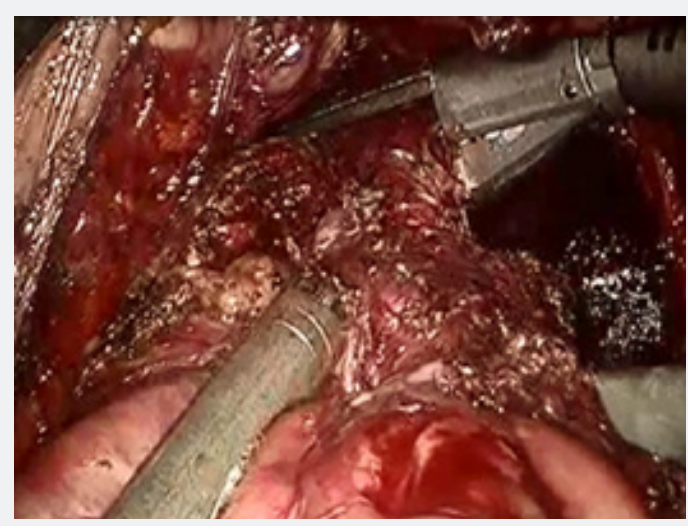

Figure 11: Intersection of the rectum.

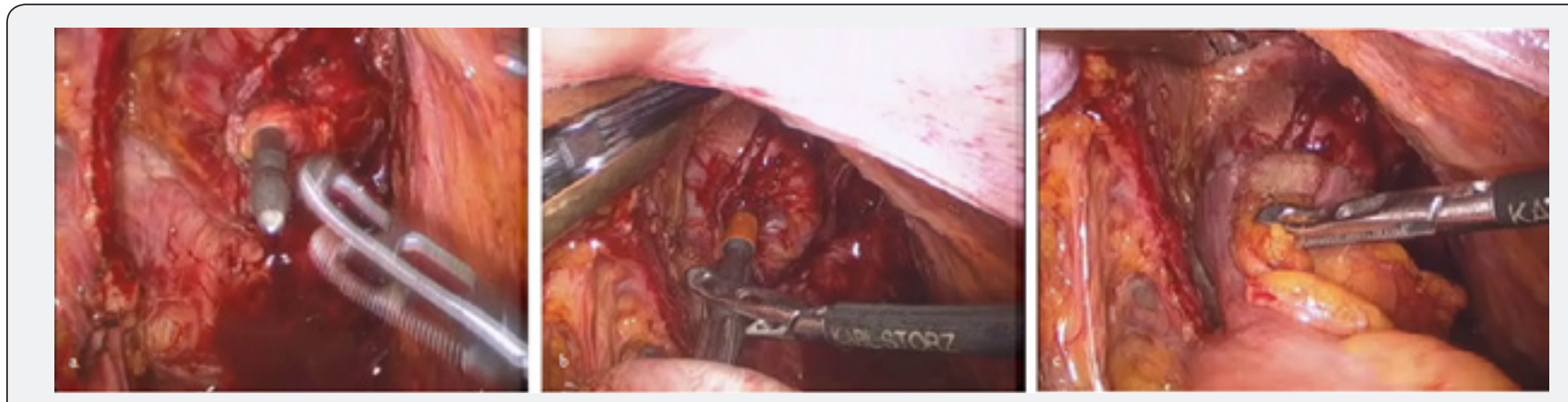

Figure 12a-c: Intracorporeal end - to - endo anastomosis. 


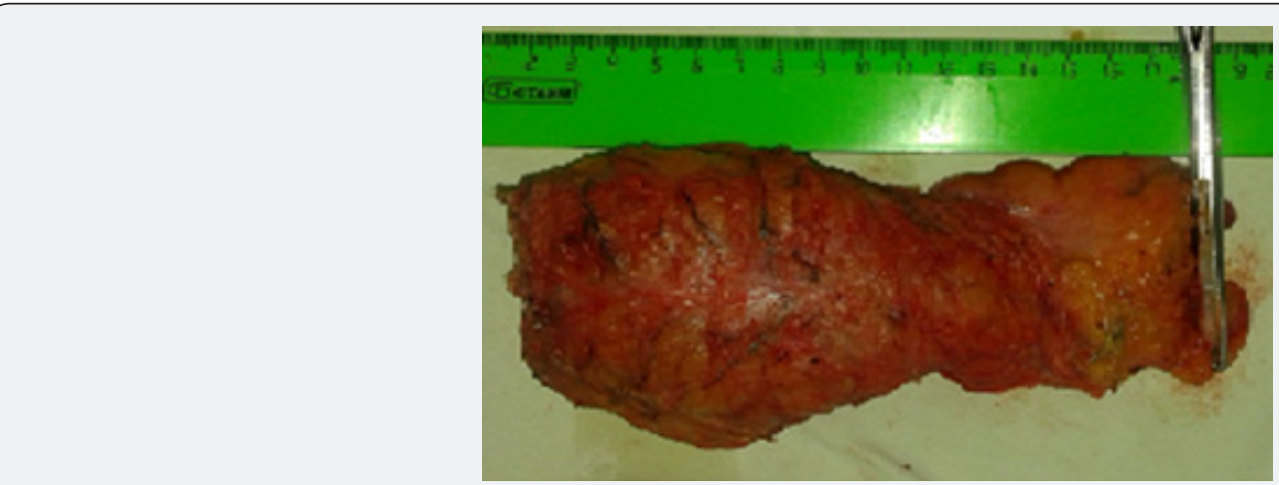

Figure 13: Rectum with mesorectum

Results

The distribution of patient in study by sex was: 10 women $(38,5 \%)$ and 16 men $(61,5 \%)$. The average age was $61,56 \pm 9,3$ years, among women $-59,2 \pm 10,5$, among men - $63,1 \pm 10,1$. The distribution of patients by stage in colorectal cancer was: 3 patients had stage I $(11,5 \%), 8$ - II $(30,8 \%), 7$ - III $(26,9 \%), 5$ - IV $(19,3 \%)$ and three were operated for benign diseases $(11,5 \%)$ (Figure 14).

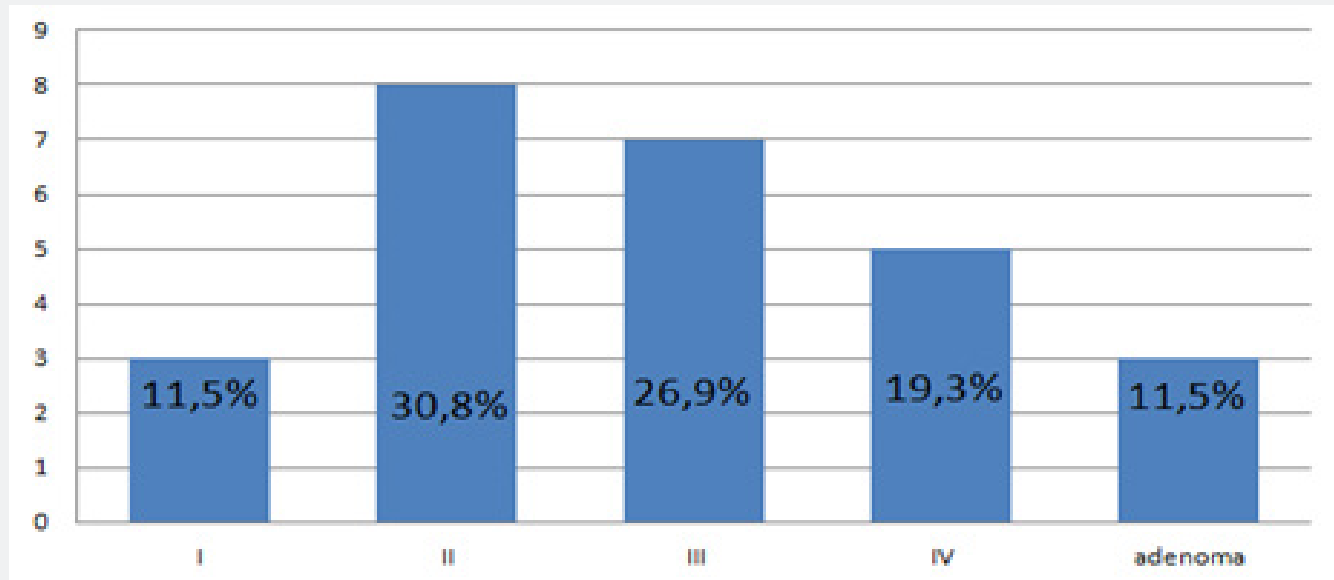

Figure 14: Distribution of patients by stages.

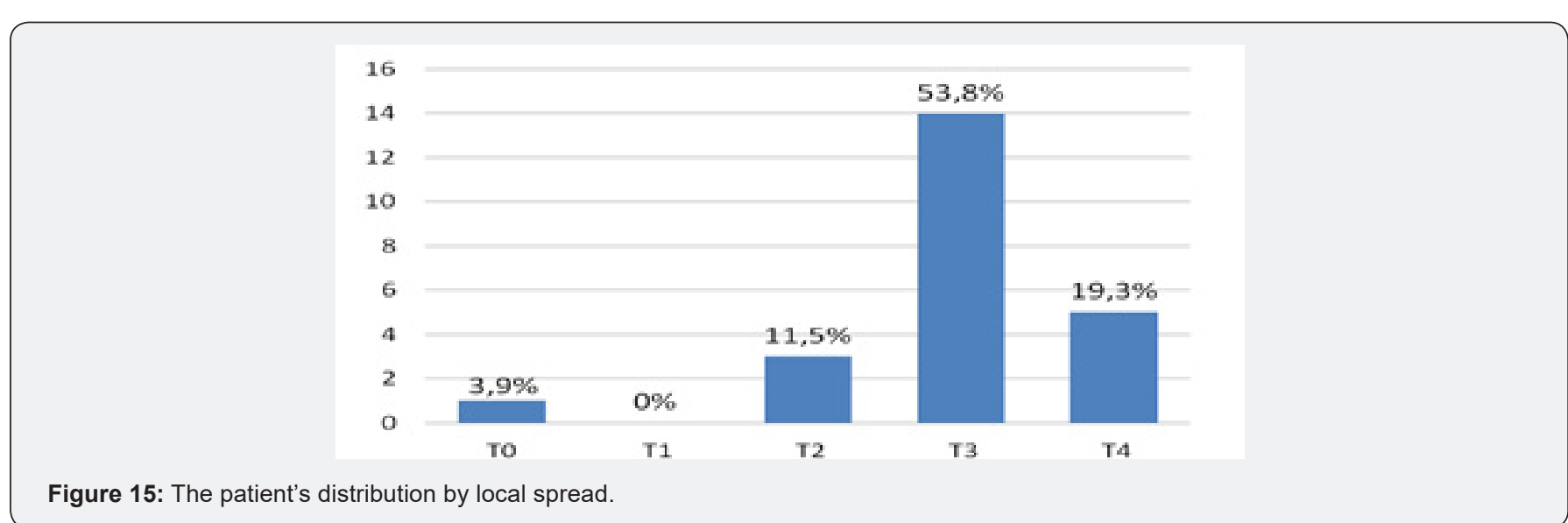

The following results were obtained from local distribution: T0 - 1 patient (3,9\%), T2 - 3 (11,5\%), T3 - 14 (53,8\%), T4 - 5 (19,3\%) (Figure 15). 17 patients $(65,4 \%)$ had severe concomitant pathology of the cardiovascular system, in $4(15,4 \%)$ - respiratory diseases, $3(11,5 \%)$ - pathology of endocrine organs (Table 1). According ASA scale, the average score was - 2,84 (2 - 4). In
19 patients we performed TME (73\%), 6 patients - underwent simultaneous rectal resection with other organs (23\%): 2 cases of them - for local advanced tumors, in 1 - due to metastatic organ damage, in other cases due to the presence of concomitant pathology (Table 2). 
Table 1: Type of comorbidities.

\begin{tabular}{|c|c|c|c|}
\hline & $\begin{array}{c}\text { The cardiovascular } \\
\text { System }\end{array}$ & $\begin{array}{c}\text { Respiratory } \\
\text { System }\end{array}$ & $\begin{array}{c}\text { Endocrine } \\
\text { System }\end{array}$ \\
\hline $\mathrm{N}$ & $17(65,4 \%)$ & $4(15,4 \%)$ & $3(11,5 \%)$ \\
\hline
\end{tabular}

Table 2: Simultaneusly resected organs.

\begin{tabular}{|c|c|c|c|c|}
\hline & Bladder & Uterus & Ovaries & Liver \\
\hline $\mathrm{N}$ & $1(3,9 \%)$ & $1(3,9 \%)$ & $3(11,5 \%)$ & $1(3,9 \%)$ \\
\hline
\end{tabular}

Table 3: Duration of surgery and bloodloss.

\begin{tabular}{|c|c|c|c|c|c|c|}
\hline $\begin{array}{c}\text { Method of } \\
\text { Operation }\end{array}$ & \multicolumn{2}{|c|}{ Hybrid Operations } & \multicolumn{3}{c|}{ Single Docking Robotic } \\
\hline Values & Average & Min & Max & Average & Min & Max \\
\hline Time (min) & 405 & 245 & 670 & 328 & 210 & 435 \\
\hline $\begin{array}{c}\text { Blood lost } \\
\text { (ml) }\end{array}$ & 255 & 50 & 60 & 172 & 50 & 600 \\
\hline
\end{tabular}

Table 4: The number of lymph nodes detected after the robotic rectal resection.

\begin{tabular}{|c|c|c|c|c|c|c|}
\hline $\begin{array}{c}\text { Type of } \\
\text { Resection }\end{array}$ & \multicolumn{3}{|c|}{ TME } & \multicolumn{3}{c|}{$\begin{array}{c}\text { Partial Mesorectum } \\
\text { Resection }\end{array}$} \\
\hline Values & Average & Min & Max & Average & Min & Max \\
\hline N & 19,6 & 14 & 45 & 14,6 & 13 & 16 \\
\hline
\end{tabular}

The average time (min) of intervention was - 358 (670-210), average blood lost (ml) - 203 (600-50). Moreover, longer surgical interventions were observed with the combined procedure of intervention, using the "Single docking technique", the average operation time was about 320 min (Table 3). When evaluating the quality of TME, there is no case with intraoperative mesorectal fascia damaging. The average number of lymph nodes detected in the mesorectal fat was 18,5 ( $\min 13$, max 45). In 10 patients $(38,5 \%)$ lymph node metastases were detected. In the case of TME, similar indicators were admitted: 19,6 (14 and 45) respectively, in case of partial mesorectal resection - 14,6 (13 and 16 ) respectively (Table 4 ).
In assessing pain, the mean value for the visual-analogue pain intensity scale was 2.1 points out of 10 possible. A qualitative assessment of the brief pain inventory showed the following results: an average score of 1.5 out of 10 possible, with a maximum value of 6.5 points recorded in only 2 patients (Table 5). The estimation of pain influence for quality of life (human ability to walk, life activity, sleep, work) - only 1 patient noticed that the pain level is considerable influent for life activity (Table 6 \& Figure 16). The average duration of painkillers intake was 2.7 days. In 1 patient we must prescribe the narcotic analgetics, $9(34,6 \%)$ patients didn't take the painkillers after surgery. The average time for urination restoration was - 2 days. According the IPS Score the mean value was 4, after 10 days -6.8 , after 6 month -3 (Table 7 \& Figure 17).

Table 5: TA qualitative assessment of pain.

\begin{tabular}{|c|c|c|c|}
\hline Intensity of pain & Minimum & Maximum & Average \\
\hline Score & 0 & 6,5 & 1,5 \\
\hline
\end{tabular}

Table 6: The influence of pain for life activity.

\begin{tabular}{|c|c|c|}
\hline \multirow{2}{*}{ Criterion } & \multicolumn{2}{|c|}{ Malue } \\
\cline { 2 - 3 } & 1,4 & Maximum \\
\hline Day-to-day activity & 0,6 & 6 \\
\hline mood & 1,7 & 5 \\
\hline The ability to go & 1.8 & 8 \\
\hline $\begin{array}{c}\text { The ability to do daily } \\
\text { work }\end{array}$ & 0.3 & 10 \\
\hline $\begin{array}{c}\text { Interrelation with } \\
\text { people }\end{array}$ & 0.8 & 5 \\
\hline Sleep & 0.8 & 7 \\
\hline $\begin{array}{c}\text { Perception of } \\
\text { enjoyment }\end{array}$ & & \\
\hline
\end{tabular}

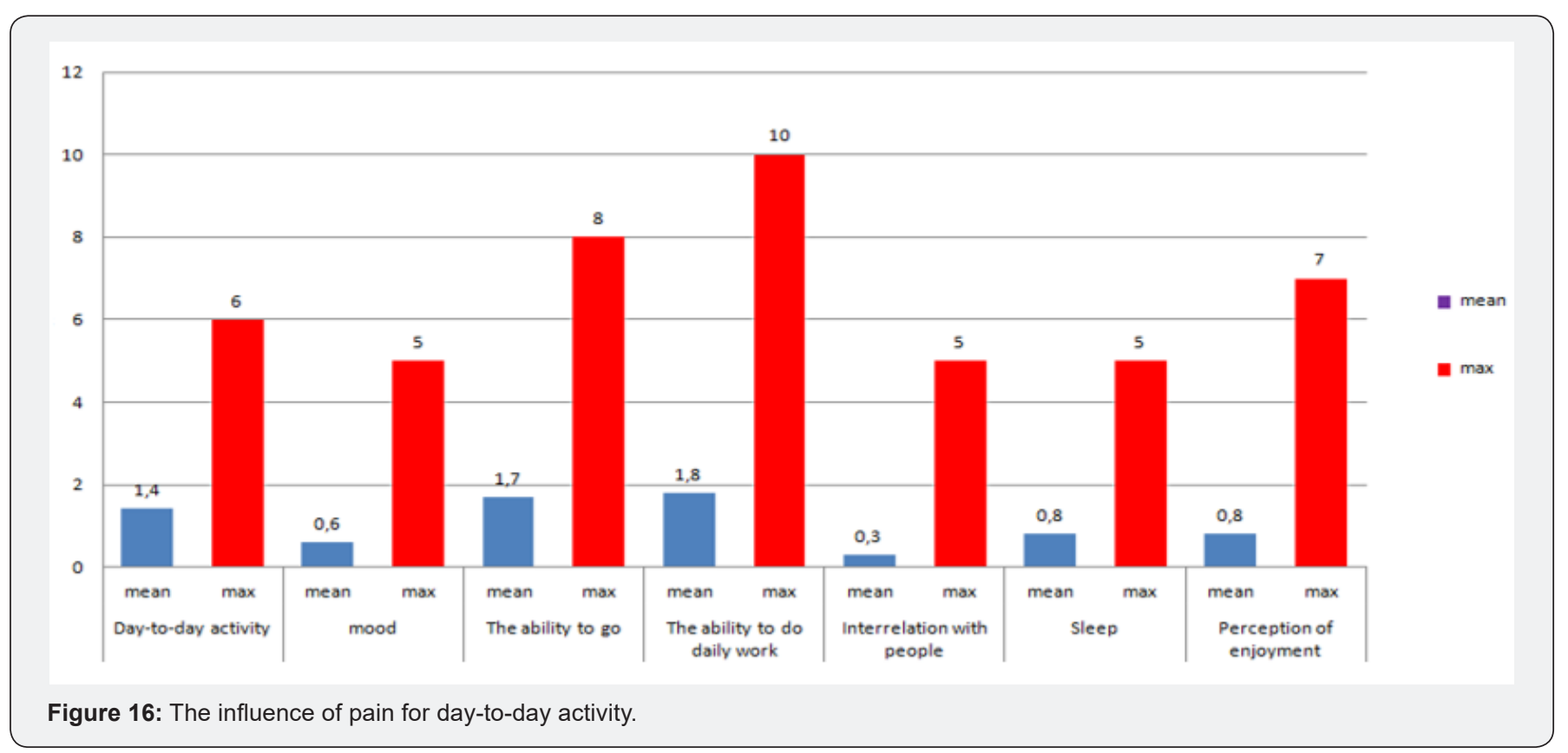




\section{Advanced Research in Gastroenterology \& Hepatology}

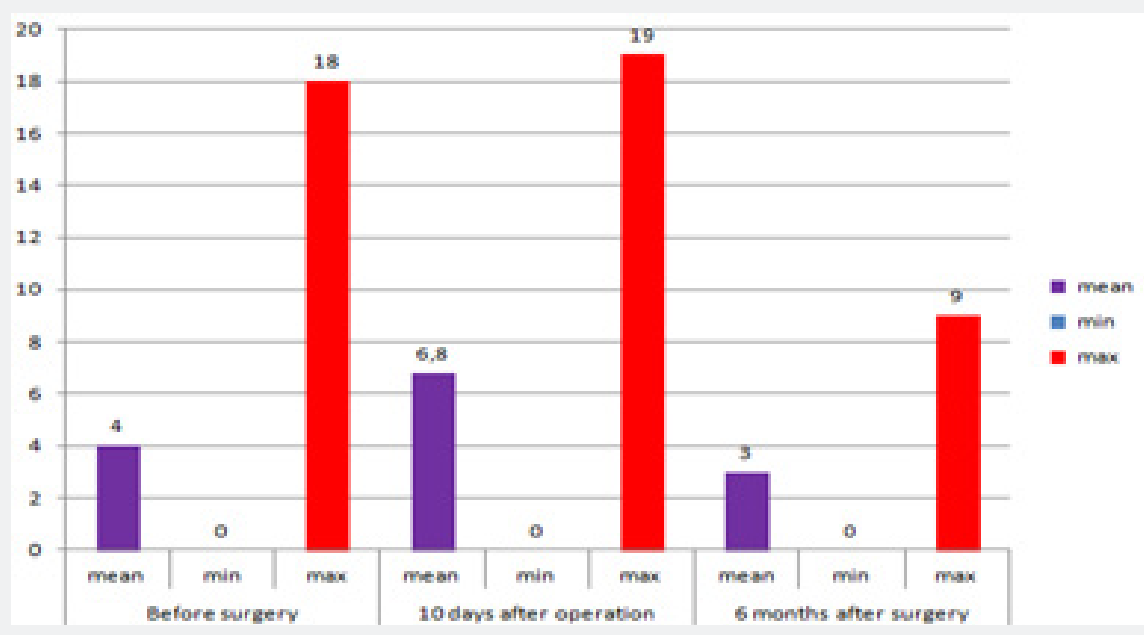

Figure 17: The urination function according IPS score.

Table 7: The number of lymph nodes detected after the robotic rectal resection.

\begin{tabular}{|c|c|c|c|c|c|c|c|c|c|}
\hline Time & \multicolumn{3}{|c|}{ Before Surgery } & \multicolumn{3}{c|}{ 10 Days After Surgery } & \multicolumn{3}{c|}{ 6 Months After Surgery } \\
\hline Value & Mean & Min & Max & Mean & Min & Max & Mean & Min & Max \\
\hline Results & 4 & 0 & 18 & 6.8 & 0 & 19 & 3 & 0 & 9 \\
\hline
\end{tabular}

Table 8: Urinary disorders.

\begin{tabular}{|c|c|c|c|}
\hline Type of Complications & Urinary Incontinence & \multicolumn{2}{|c|}{ Urinary Retention } \\
\hline & & Bladder Hypotonia & Bladder Atonia \\
\hline Number, N & 0 & 3 & 1 \\
\hline$\%$ & 0 & 11,5 & 3,9 \\
\hline
\end{tabular}

Table 9: Anal continence by Wexner Score.

\begin{tabular}{|c|c|c|c|c|c|c|c|c|c|}
\hline Time & \multicolumn{3}{|c|}{ Before Surgery } & \multicolumn{3}{c|}{ 10 Days After Surgery } & \multicolumn{3}{c|}{ 6 Months After Surgery } \\
\hline Value & Median & Min & Max & Median & Min & Max & Median & Min & Max \\
\hline Results & 2,7 & 0 & 7 & 3,1 & 1 & 8 & 1,5 & 0 & 4 \\
\hline
\end{tabular}

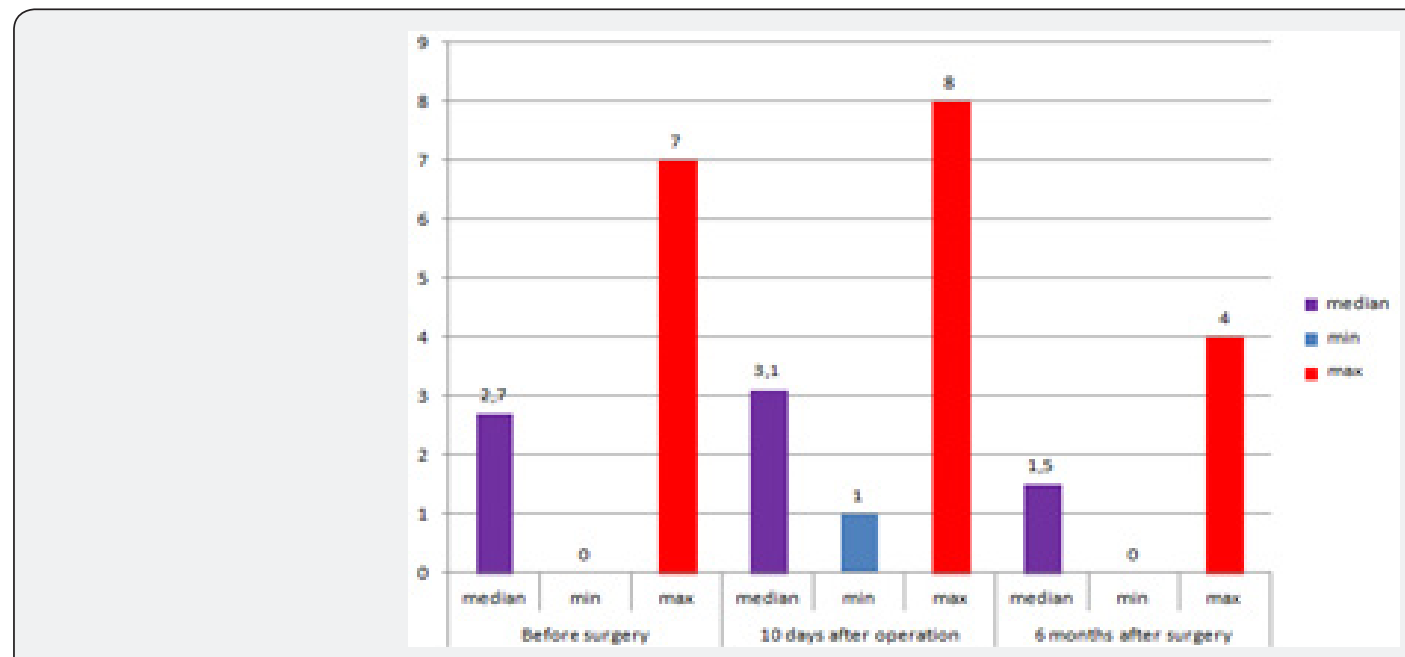

Figure 18: Anal continence by wexner score.

In $3(11,5 \%)$ cases we estimated the different degree of urinary disorders, 1 patient $(3,9 \%)$ - bladder atony was the rison for recathetherization and epicystostomy finally performed (the urination will restore 4 months later) (Table 8). Anal continence according Wexner Score scale: before surgery median was 2.7
(0-7), 10 days after surgery - 3.1 (1-8), 6 months after surgery$1.6(0-4)$ (Table 9 \& Figure 18). One patient $(3,9 \%)$ underwent reoperation for early adhesive obstruction. Median hospital stay was 11 days. The ultraprecision robotic technique for rectal surgery could increase the qoulity of TME and lymphodissection, 
preservation of autonomic nerve system of the pelvis, reducing the number of pelvic organs disorders in postoperative period.

\section{References}

1. Lange MM, Rutten HJ, van de Velde CJ (2009) One hundred years of curative surgery for rectal cancer: 1908(2008). Europ J Surg Oncol 35(5): 456-463.

2. Havenga K., DeRuiter MC, Enker WE, Welvaart K (1996) Anatomical basis of autonomic nerve-preserving total mesorectal excision for rectal cancer. Br J Surg 83(3): 384-388.

3. Heald RJ, Chir M, Smedh RK, Sexton R, Moran BJ (1997) Abdominoperineal excision of the rectum - an endangered operation. Dis Colon Rectum 40(7): 747-751.

4. Heald RJ, Husband EM, Ryall RD (1982) The mesorectum in rectal cancer surgery-the clue to pelvic recurrence? Brit J Surg 69(10): 613616.

5. WE Enker, HT Thaler, ML Cranor, T Polyak (1995) Total mesorectal excision in the operative treatment of carcinoma of the rectum. J Am Coll Surg 181(4); 335-346.

6. Vecchio R, MacFayden BV, Palazzo F (2012) The history of laparoscopic surgery. Oncological coloproctology 42(2): 35-39.
7.Atroshchenko AO (2012) The history of laparoscopic surgery in oncoproctology. Herald of N.N. Blokhins Russian Oncological Science Center. 23(1): 3-9.

8. Atroshchenko AO Igor Khatkov, Stepan Pozdnyakov, Mikhail Danilov (2014) Laparoscopic cytoreductive surgery for metastatic colon cancer. Journal of Coloproctology 37(2): 90-94.

9. Atroshchenko AO (2014) The history of robotic surgery and it place in colorectal surgery: Literature review. Malignant tumors 1: 3-14.

10. Ballantyne GH, Merola P, Weber A, Wasielewski A (2001) Robotic solutions to the pit falls of laparoscopic colectomy. Osp Ital Chir 7: 405-412.

11. Jones SB., Jones DB, Daniel B.Jones (2001) Surgical aspects and future developments in laparoscopy. Anesthiol Clin North Am 19(1): 107-124.

12. Kim VB., Chapman WH., Albrecht RJ, Bailey BM, Young JA, et al. (2002) Early experience with telemanipulative robot-assisted laparoscopic cholecystectomy using Da Vinc. Surg Laparosc Endosc Percutan Tech 12(1): 34-40.

13. Satava RM, Bowersox JC, Mack M (2001) Robotic surgery: state of the art and future trends. Contemp Surg 57: 489-499.

\section{Your next submission with JuniperPublishers will reach you the below assets}

- Quality Editorial service

- Swift Peer Review

- Reprints availability

- E-prints Service

- Manuscript Podcast for convenient understanding

- Global attainment for your research

- Manuscript accessibility in different formats

( Pdf, E-pub, Full Text, audio)

- Unceasing customer service

Track the below URL for one-step submission https://juniperpublishers.com/online-submission.php 